\title{
Effects of Nano-Clay on Physical and Mechanical Properties of Medium- Density Fiberboards Made from Wood and Chicken- Feather Fibers and Two Types of Resins
}

\section{Utjecaj nanogline na fizička i mehanička svojstva ploča vlaknatica srednje gustoće izrađenih od drva, vlakana pilećeg perja i dviju vrsta smola}

\author{
Original scientific paper • Izvorni znanstveni rad \\ Received-prispjelo: 1. 11. 2017. \\ Accepted-prihvaćeno: 27. 11. 2018. \\ UDK: $630 * 812.122 ; 630 * 812.71 ; 630 * 861.15 ; 630 * 863.312$ \\ doi:10.5552/drind.2018.1761
}

\begin{abstract}
Medium-density fiberboards (MDF) were produced, using two different resins of urea-formaldehyde (UF) and phenol-formaldehyde (PF) at $10 \%$ and $8 \%$ contents, respectively. In order to find new source of raw material to satisfy the increasing need of composite manufacturing industry, $10 \%$ of chicken feather was added to the furnish. Moreover, nano-clay was added to investigate its potential improving effects on MDF panel properties. Results showed that panels with PF resin demonstrated significantly lower water absorption and thickness swelling values in comparison to the panels with UF resin. However, mechanical properties of panels containing UF resin were generally higher; this was partially attributed to the higher resin content. It was concluded that panels with PF resin are recommended for applications where panels may be more exposed to water and vapor. In cases where the mechanical properties are of prime importance, panels with UF resin are more preferable. NC can be recommended in panels containing UF-resin to improve the properties, while it is not recommended in panels with PF-resin. Moreover, chicken feather can be included in MDF furnish to provide part of raw materials, though its addition can have diminishing effect on the properties to some extent.
\end{abstract}

Key words: feather fibers, mineral materials, nano-composites, clay nanofibers, wood fiber

SAŽETAK • Ploče vlaknatice srednje gustoće (MDF) izrađene su uz dodatak dviju različitih smola, ureaformaldehidne (UF) i fenolformaldehidne (PF), i to u udjelu od 10 odnosno $8 \%$. Kako bi se pronašao novi izvor sirovine i pritom zadovoljile povećane potrebe industrije kompozitnih materijala, smjesi sirovine za izradu ploča vlakna-

\footnotetext{
Authors are assistant professor, associate professor and MS student of Wood Science \& Technology Department, Faculty of Materials Engineering and New Technologies, Shahid Rajaee Teacher Training University, Tehran, Iran.

Autori su docent, izvanredni profesor i student diplomskog studija Odsjeka za znanost o drvu i tehnologiju, Fakultet strojarstva i novih tehnologija, Učiteljsko sveučilište Shahid Rajaee, Teheran, Iran.
} 
tica dodano je $10 \%$ pilećeg perja. Nadalje, dodana joj je i nanoglina da bi se istražilo moguće poboljšanje MDF ploča. Rezultati su pokazali da su ploče s PF smolom znatno slabije upijale vodu i da im je debljinsko bubrenje u odnosu prema pločama s UF smolom bilo manje. Međutim, mehanička svojstva ploča koje su sadržavale UF smolu u osnovi su bila bolja, što je djelomično povezano s većim udjelom smole. Zaključeno je da se ploče s PF smolom preporučuju za primjenu u uvjetima veće izloženosti vodi i pari. Kada su, pak, važnija mehanička svojstva ploča, pogodnije su one s UF smolom. Nanoglina se preporučuje za poboljšanje svojstava ploča koje sadržavaju UF smolu, a ne preporučuje se za ploče s PF smolom. Nadalje, pileće se perje može dodati sirovini za izradu MDF ploča iako ono može donekle pridonijeti pogoršanju svojstava ploče.

Ključne riječi: vlakna od perja, mineralni materijali, nanokompoziti, nanovlakna gline, drvna vlakna

\section{INTRODUCTION}

1. UVOD

Wood is a renewable material for many applications that helped mankind keep a sustainable development over centuries of civilization (Daly-Hassan et al., 2014; Fernandez et al., 2014 and 2017; Arce and Moya, 2015). Fast-growing species provide an opportunity to provide the raw materials necessary for wood industries and composite products (Behling et al., 2011; Gbetoho et al., 2017); however, the wood produced of these trees is usually of low quality and density and it is usually more susceptible to wood deteriorating bioagents (Schmidt, 2006; de Medeiros et al., 2016; Schmidt et al., 2016; Ayata et al. 2017). Therefore, many modification techniques were used to improve its properties (Hill, 2006). However, it is mostly used in composite panels, engineered wood, and paper manufacturing industries (Candan and Akbulut, 2014; Bastani et al., 2016; Andrade et al., 2016; Behr et al., 2017; Hubbe et al., 2017). In this connection, composite panels not only provide a homogeneous material but they also offer boards with large length and width (Eshaghi et al., 2013; Mendes et al., 2013; Tajvidi et al., 2016; Altuntas et al., 2017) and therefore, there have been many studies elaborating on composite panels (Malanit et al. 2005; Valenzuela et al., 2012). However, for a steady production of composite panels, a continuous flow of raw materials is essential. Iran is short of woody materials and therefore, many other substitutes have been considered (Hosseinkhani, 2015).

Feather fibers were reported to be used in some materials including concrete (Hamoush \& El-Hawary, 1994; Koch, 2006; Acda, 2010). In an official report by the Ministry of Jihad-e-Agriculture of Iran, the chicken feather produced in 2012 was about 80,000 metric tons in Iran. This amount of chicken feather would be enough to manufacture more than 20 million composite panels with standard size of $366 \times 183 \times 16 \mathrm{~mm}$ with $5 \%$ feather content. Other countries also produce immense amount of chicken feather on a monthly basis. Chicken feathers from poultry farms used to be a valuable filling for blankets and matrices. However, synthetic materials substituted this natural substance and now chicken feathers are considered waste materials in Iran. Application of a percentage of chicken feathers in composite panels were studied before and the results were promising (Winandy et al., 2003 and 2007; Taghiyari et al., 2014ab; Taghiyari and Sarvari, 2016). However, the cited authors (Winandy et al.
2003 and 2007) only used phenol-formaldehyde (PF) resin in their study. Though PF is very practical in many applications, it is not popular in composite-manufacturing countries in Iran and some South-East Asian countries like Malaysia. Therefore, urea-formaldehyde (UF) resin was used here along with PF for comparison purposes. In addition, previous studies used quill-free feathers, that is, quills were removed from feathers. The process of removing quills is costly, adding to the final cost of the composite panels produced. Therefore, in the present study, the whole feather was used in the production of composite panels.

Moreover, nanomaterials have been successful in improving properties in many materials (Majidi, 2016; Harsini et al., 2017; Matinise et al., 2016; Pethig, 2017; Sandeep et al. 2017; Suganya et al., 2017). In wood science and technology, different metal and mineral nanomaterials were used to decrease hot-pressing in wood-composite panels, to improve biological resistance of solid wood and composites, and to ameliorate the negative effects of thermal modification. In the present research project, nano-clay was also added as an additive to the resins to investigate its effects.

\section{MATERIALS AND METHODS} 2. MATERIJALI I METODE

\subsection{Specimen procurement}

\subsection{Nabava uzoraka}

Composite panels were manufactured from a mixture of five species of poplar, alder, hornbeam, maple and beech. The final thickness of panels was $16 \mathrm{~mm}$ with a density of $0.67 \mathrm{~g} / \mathrm{cm}^{3}$. Two types of resins were separately used for panels, namely urea-formaldehyde (UF) and phenol-formaldehyde (PF) resins. Specifications of the resins are given in Table 1.

Urea-formaldehyde (UF) and phenol-formaldehyde $(\mathrm{PF})$ resins were procured from Dehghani Co. and Iran Composite Co. in Iran, respectively. The temperature and duration of hot press was $175^{\circ} \mathrm{C}$ and 8 minutes, and $200{ }^{\circ} \mathrm{C}$ and 6 minutes for UF and PF resins, respectively. Once produced, panels were kept in conditioning chamber $\left(25^{\circ} \mathrm{C}\right.$, and $40 \pm 3 \%$ relative humidity) for four weeks before being cut, ready for tests. The moisture content of the specimens were measured at the time of testing to be $7.4 \%$ in all treatments, because wood has a thermo-hygromechanical behavior and its properties depend on the combined action of temperature, relative humidity, and mechanical load variations (Figueroa et al., 2012). Five replicate boards 
Table 1 Specifications of urea-formaldehyde (UF) and phenol-formaldehyde (PF) resins

Tablica 1. Specifikacija ureaformaldehidne (UF) i fenolformaldehidne (FF) smole

\begin{tabular}{|c|c|c|c|c|c|}
\hline $\begin{array}{c}\text { Resin type } \\
\text { Vrsta smole }\end{array}$ & $\begin{array}{c}\text { Color } \\
\text { Boja }\end{array}$ & $\begin{array}{c}\text { Solid content, \% } \\
\text { Sadržaj suhe tvari, \% }\end{array}$ & $\begin{array}{c}\text { Solvent } \\
\text { Otapalo }\end{array}$ & $\begin{array}{c}\text { Producer } \\
\text { Proizvođač }\end{array}$ & $\begin{array}{c}\text { Country of origin } \\
\text { Država podrijetla }\end{array}$ \\
\hline UF & $\begin{array}{c}\text { Transparent } \\
\text { prozirna }\end{array}$ & 0.58 & Water / voda & Dehghani Co. & Iran \\
\hline PF & Red / crvena & 0.78 & Thinner / razrjeđivač & Iran Composite Co. & Iran \\
\hline
\end{tabular}

Table 2 Molecular specifications of serine (Taghiyari and Sarvari, 2016)

Tablica 2. Molekularna specifikacija serina (Taghiyari i Sarvari, 2016.)

\begin{tabular}{|c|c|}
\hline Molecular formula / Molekularna formula & $\mathrm{C}_{3} \mathrm{H}_{7} \mathrm{NO}_{3}$ \\
\hline Molecular weight / Molekularna masa & $105.09 \mathrm{~g} \mathrm{~mol}^{-1}$ \\
\hline Isoelectric point $(\mathrm{pH}) /$ Izoelektrična točka $(\mathrm{pH})$ & 5.68 \\
\hline $\mathrm{pK}_{\mathrm{a}}$ values / $p K_{a}$ vrijednost & $2.21,9.15$ \\
\hline Density / Gustoća & $1.603 \mathrm{~g} / \mathrm{cm}^{3}\left(22^{\circ} \mathrm{C}\right)$ \\
\hline Melting point / Talište & $246^{\circ} \mathrm{C}$ \\
\hline Acidity $\left(\mathrm{p} K_{a}\right) /$ Kiselost $\left(p K_{a}\right)$ & 2.21 (carboxyl), 9.15 (amino) \\
\hline
\end{tabular}

were produced for each treatment. From each board, two specimens were cut for each kind of test.

Chicken feathers were bought from a chicken farm located in Ghazvin city, Ghazvin Province. Only the feathers of the chicken body were used because the quills of the wing feathers were thick and inflexible. Moreover, the process of removing the quills of wing feathers is not commercially competitive for composite manufacturing factories. The chemical combinations of chicken feathers are given in Table 2 . As can be observed, they are mostly comprised of serine $\left(\mathrm{C}_{3} \mathrm{H}_{7} \mathrm{NO}_{3}\right)$.

\subsection{Nano-clay application}

\subsection{Nanošenje nanogline}

Nano-clay (NC) powder was produced in cooperation with Mehrabadi Manufacturing Company in Tehran, Iran. The size range of nanoparticles was 30-110 $\mathrm{nm}$. NC composition is given in Table 3. NC was mixed with the resins and sprayed on to the wood fibers in a rotary drum-mixer before the hot press. A magnetic mixer stirred the resin-nanoclay mixture for 25-30 minutes for each production batch before being sprayed on the furnish. Consumption level of NC powder was $10 \%$ based on the dry weight of the composite mat.

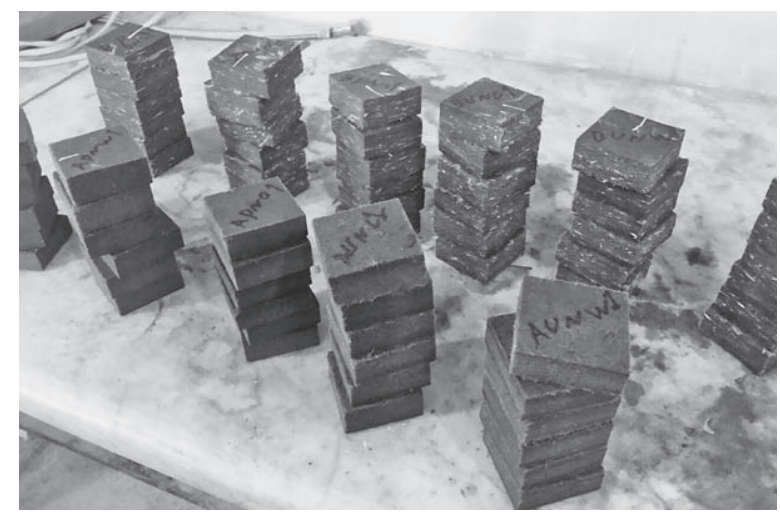

Figure 1 Water absorption and thickness swelling specimens after being immersed in distilled water for 24 hours Slika 1. Uzorci za određivanje upijanja vode i bubrenja nakon 24-satnog potapanja uzoraka u destiliranoj vodi
Table 3 Composition of the nano-clay used in the present research project

Tablica 3. Sastav nanogline primijenjene u istraživanju

\begin{tabular}{|c|c|}
\hline $\begin{array}{c}\text { Component } \\
\text { Komponenta }\end{array}$ & $\begin{array}{c}\text { Proportion (\%w/w) } \\
\text { Udio (\% w/w) }\end{array}$ \\
\hline $\mathrm{CaO}$ & 1.97 \\
\hline $\mathrm{SiO}_{2}$ & 50.95 \\
\hline $\mathrm{Al}_{2} \mathrm{O}_{3}$ & 19.60 \\
\hline $\mathrm{Fe}_{2} \mathrm{O}_{3}$ & 5.62 \\
\hline $\mathrm{TiO}_{2}$ & 0.62 \\
\hline $\mathrm{K}_{2} \mathrm{O}$ & 0.86 \\
\hline $\mathrm{MgO}$ & 3.29 \\
\hline $\mathrm{Na}_{2} \mathrm{O}$ & 0.98 \\
\hline $\mathrm{LOI}$ & 15.45 \\
\hline
\end{tabular}

\subsection{Physical and mechanical tests}

2.3. Fizička i mehanička ispitivanja

Physical and mechanical tests, as well as number and location of the specimens, were carried out in accordance with the Iranian National Standard ISIRI 9044 PB Type P2 (compatible with ASTM D1037-99) specifications, using INSTRON 4486 test machine, with five $\mathrm{kN}$ capacity. Figures 1 and 2 show thickness swelling and MOR specimens, ready for measurement.

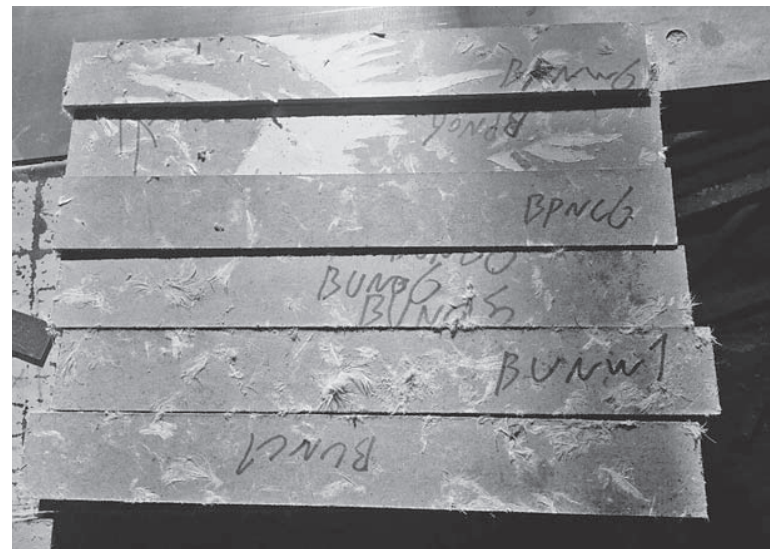

Figure 2 Surface of MOR specimens with feather content Slika 2. Površina uzoraka s perjem za određivanje modula loma 


\subsection{Statistical analysis}

\subsection{Statistička analiza}

Statistical analysis was conducted using SAS software program, version 9.2 (2010). One-way ANOVA was performed to discern significant difference at the $95 \%$ level of confidence. Grouping was made between treatments, using the Duncan's multiple range test. Hierarchical cluster analysis, including dendrogram and using Ward methods with squared Euclidean distance intervals, was carried out by SPSS/18 (2010). Cluster analysis was performed to find similarities and dissimilarities between treatments based on more than one property simultaneously. The scaled indicator in each cluster analysis shows how much treatments are similar or different; lower scale numbers show more similarities, while higher ones show dissimilarities (Taghiyari et al., 2014ab). Surface and contour plots were made by Minitab software, version 16.2.2 (2010).

\section{RESULTS AND DISCUSSION} 3. REZULTATI I RASPRAVA

Results showed that MOR values of panels produced with UF-resin were higher when the composite furnish was comprised only of wood fibers (Figure 3). This was attributed to the higher UF-resin content (10 $\%$ ) in comparison to PF-resin content (8\%). Addition of chicken feathers resulted in a decrease in MOR values in all treatments, though the decreases were not statistically significant in some cases. The decrease was partially attributed to the incompatibility of resins with the chemical components of feather. Similar chemical incompatibility between UF-resin and chicken feather components were reported to decrease biological resistance of composite panels (Taghiyari et al., 2014ab), and to increase liquid permeation (Taghiyari \& Sarvari, 2016). Addition of NC to the composite furnish reacted differently in each treatment. In panels with $100 \%$ wood fibers and UF resin, NC improved MOR values by $10.7 \%$. This was because NC acted as a filler in UF resin, improving the overall strength of the composite matrix. Similar improvement was reported by addition of other minerals. However, in panels produced with PF-resin, resin content was lower $(8$ $\%$ ) and part of the resin was absorbed by NC particles, avoiding this portion to be actively involved in the process of sticking the fibers together; ultimately MOR values decreased, though the amount of decrease was not significant. No significant difference was observed by addition of NC to panels with $10 \%$ feather-content. It was concluded that $\mathrm{NC}$ can act as a filler and improve MOR values only in panels produced with UFresin.

Modulus of elasticity (MOE) values illustrated somehow different trends in comparison to MOR values. Addition of chicken feather to the furnish generally improved MOE values in the produced MDF panels (Figure 4). This was a result of higher flexibility of feather fibers in comparison to wood fibers. Addition of $\mathrm{NC}$ to the furnish significantly decreased MOE values only in panels with PF-resin and feather content, similar to the decrease that occurred in MOR value of this treatment.

Results of water absorption (WA) measurements showed significant difference between panels produced with UF-resin and those produced with PF-resin (Figure 5). Panels with PF-resin generally showed lower WA values. This was due to the BWP (boil and water proof) nature of this resin. To be specific, lower WA values were achieved in panels produced with PF-resin

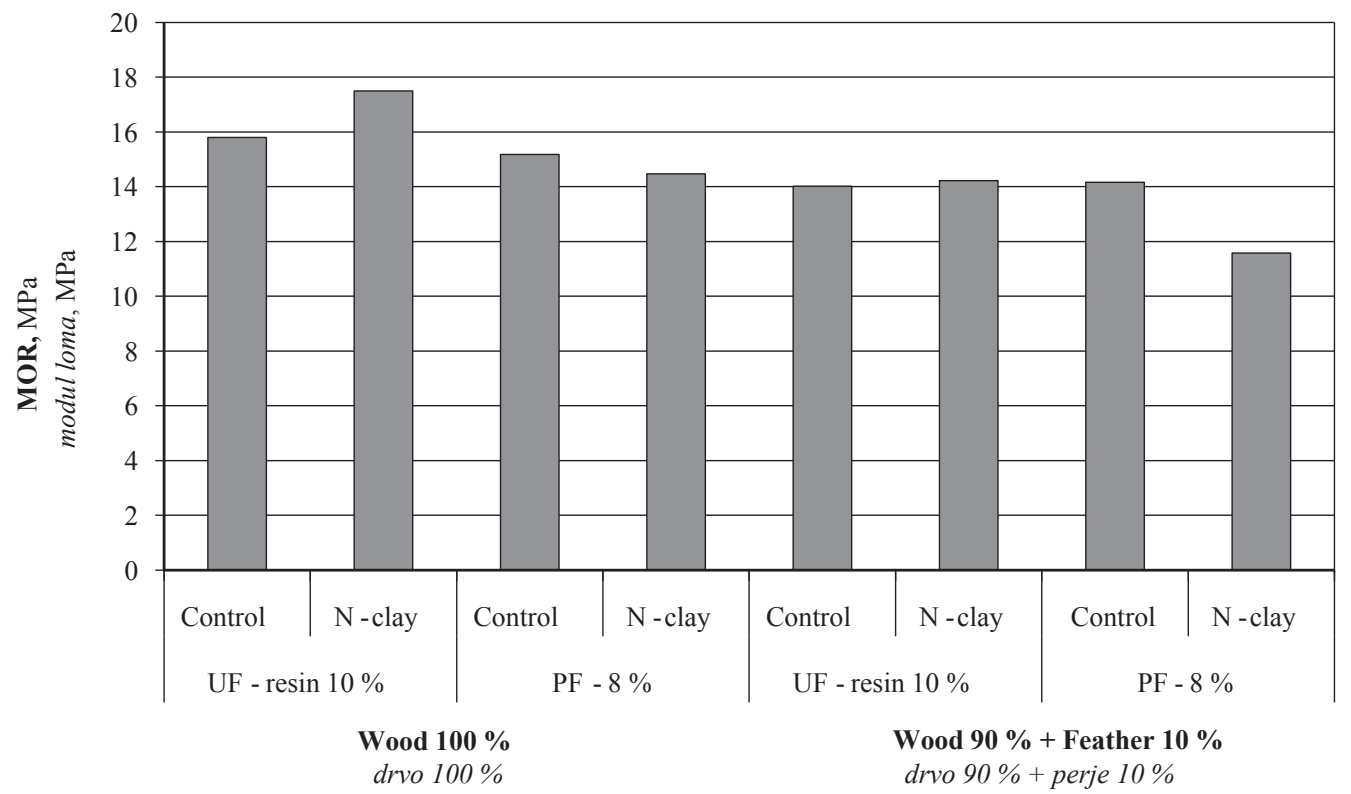

Figure 3 Modulus of rupture (MOR) values (MPa) in eight treatments of medium-density fiberboard (N - Nano; UF - urea-formaldehyde resin; PF - phenol-formaldehyde resin)

Slika 3. Vrijednosti (u MPa) modula loma (MOR) osam različitih ploča vlaknatica srednje gustoće (N - nanočestice; UF - ureaformaldehidna smola; PF - fenolformaldehidna smola) 


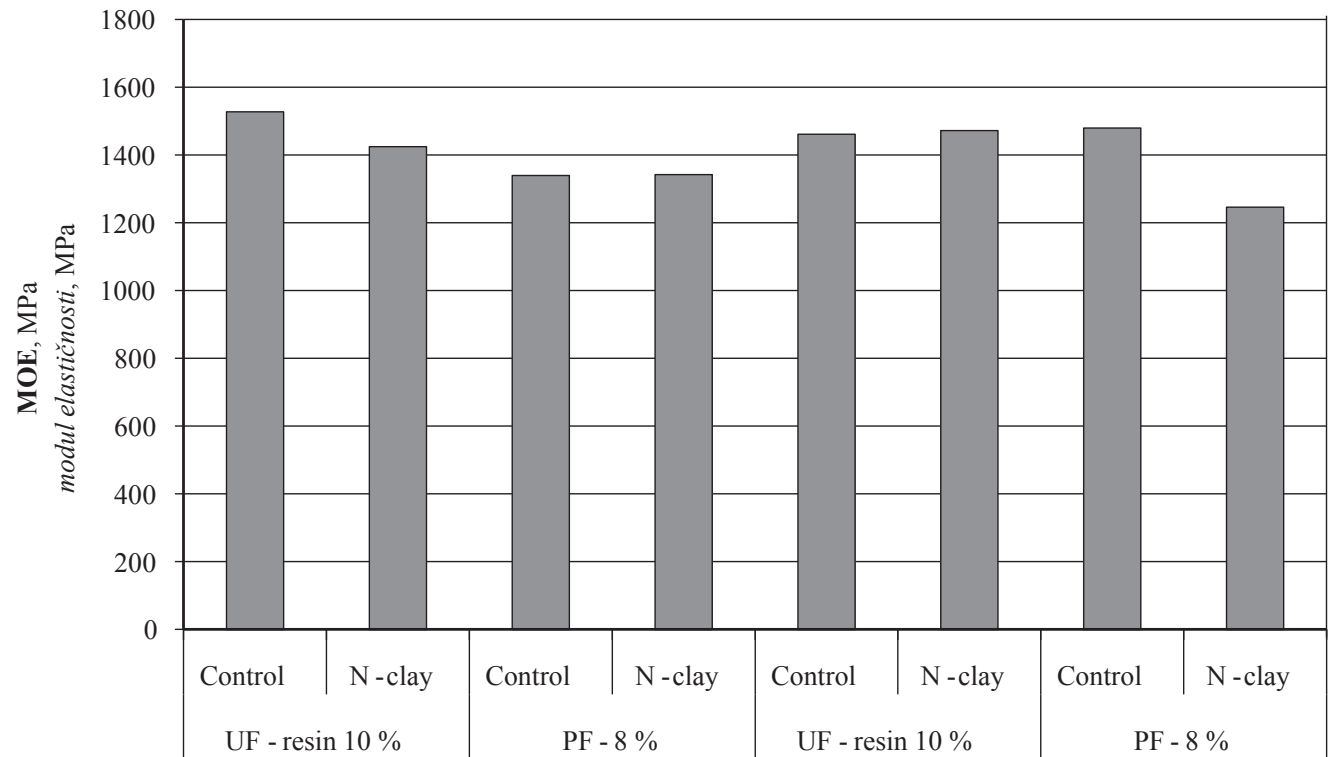

Wood $100 \%$

drvo $100 \%$

Wood $90 \%$ + Feather $10 \%$

drvo $90 \%+$ perje $10 \%$

Figure 4 Modulus of elasticity (MOE) values (MPa) in eight treatments of medium-density fiberboard (N - Nano; UF - urea-formaldehyde resin; PF - phenol-formaldehyde resin)

Slika 4. Vrijednosti (u MPA) modula elastičnosti(MOE) osam različitih ploča vlaknatica srednje gustoće (N - nanočestice; UF - ureaformaldehidna smola; PF - fenolformaldehidna smola)

although PF-resin content ( $8 \%$ ) was $2 \%$ lower than UF-resin content $(10 \%)$, and this was because of water resistance nature of PF-resin. Addition of feather did not have statistically significant effect on WA values.

Thickness swelling (TS) values generally followed the same trend as WA values, though the improving effects of PF-resin were more conspicuous on TS values in comparison to WA values (Figure 6). Addition of NC generally did not affect TS values, though there were some fluctuations. It was concluded that in MDF composite panel production, when water resistance is of prime importance, PF-resin is more preferable than UF-resin, though lower PF-resin provided an edge of commercial competition over UF-resin.

Results of the surface analysis showed clear inverse relationship between MOR values versus both WA and TS values in panels produced with PF-resin (Figure 7). In panels produced with UF-resin, no clear

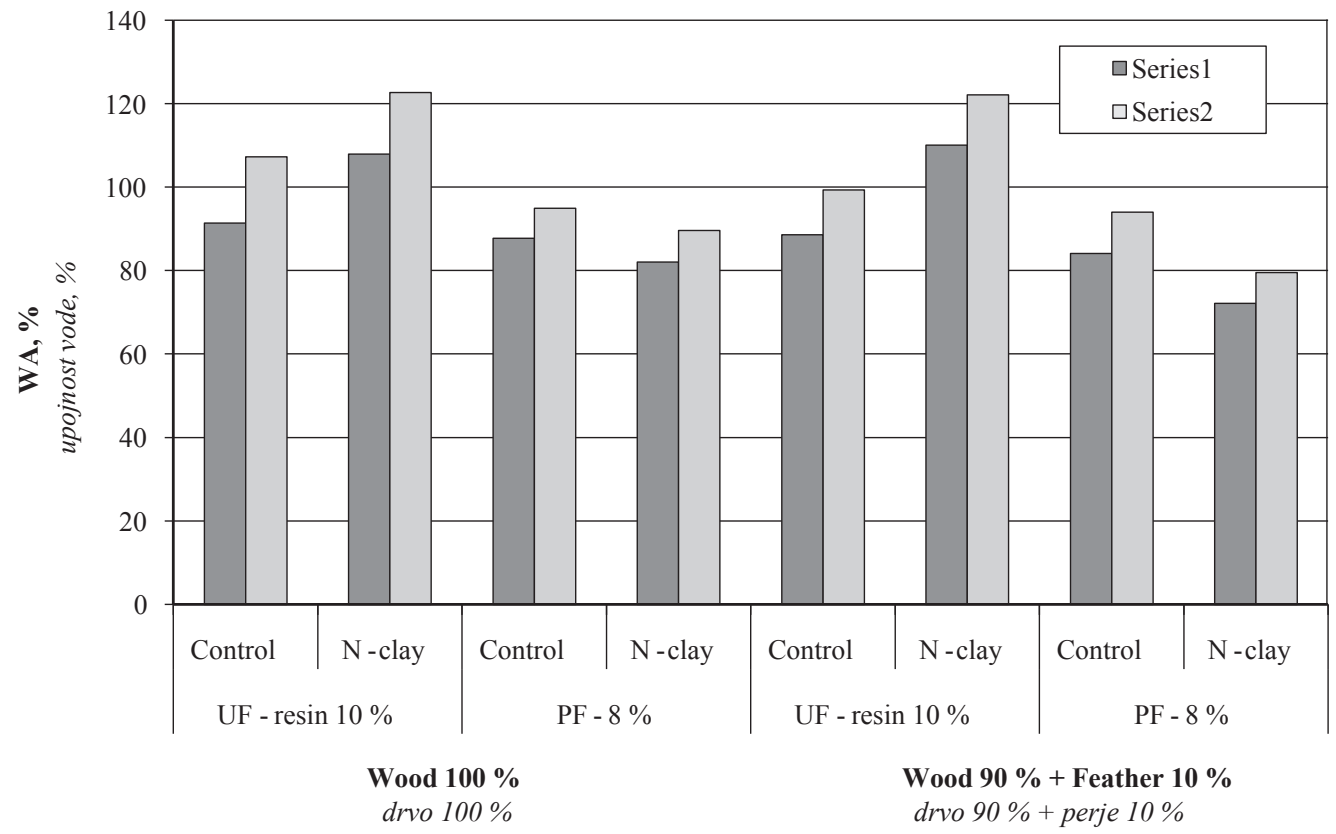

Figure 5 Water absorption (WA) values (\%) in eight treatments of medium-density fiberboard (N - Nano; UF - urea-formaldehyde resin; $\mathrm{PF}$ - phenol-formaldehyde resin)

Slika 5. Postotak upijanja vode (WA) osam različitih ploča vlaknatica srednje gustoće (N - nanočestice; UF - ureaformaldehidna smola; PF - fenolformaldehidna smola) 


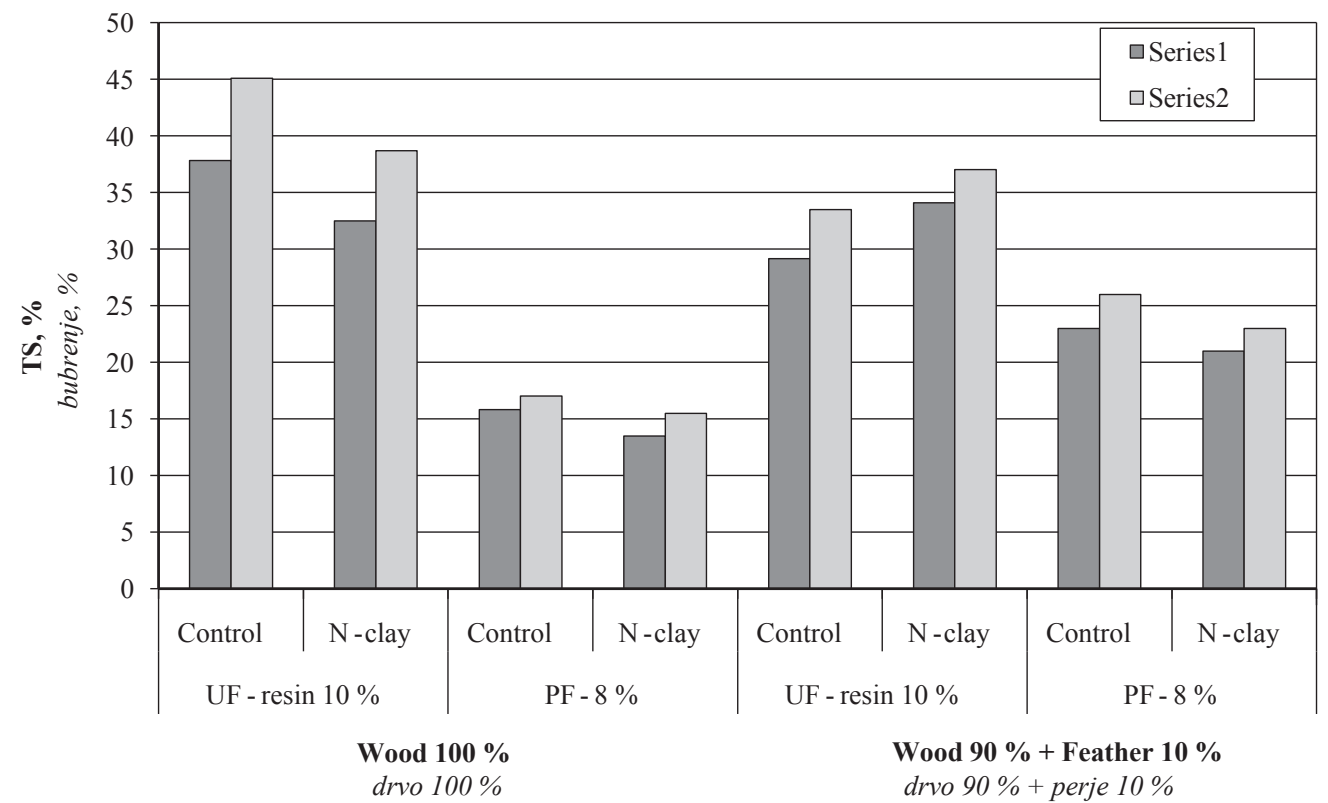

Figure 6 Thickness swelling (TS) values (\%) in eight treatments of medium-density fiberboard (N - Nano; UF - urea-formaldehyde resin; $\mathrm{PF}$ - phenol-formaldehyde resin)

Slika 6. Postotak bubrenja (TS) osam različitih ploča vlaknatica srednje gustoće (N - nanočestice; UF - ureaformaldehidna smola; PF - fenolformaldehidna smola)

relationship was found between MOR versus WA and TS. The inverse relationship indicated that, in panels containing PF-resin, physical stability of MDF panels can easily be anticipated with regard to their mechanical property of MOR values. However, in panels produced with UF-resin, the interactions between different production factors of NC-content and feather-content were so high, varying from treatment to treatment, that ultimately it made no clear anticipation possible.

Contour plots clearly demonstrated inverse relationship between MOE versus WA and TS values in panels produced with PF-resin (Figure 8A). Contour plot between MOR versus WA and TS demonstrated direct relationship between MOR versus WA values, but inverse relationship versus TS (Figure $8 \mathrm{~B}$ ). The in-

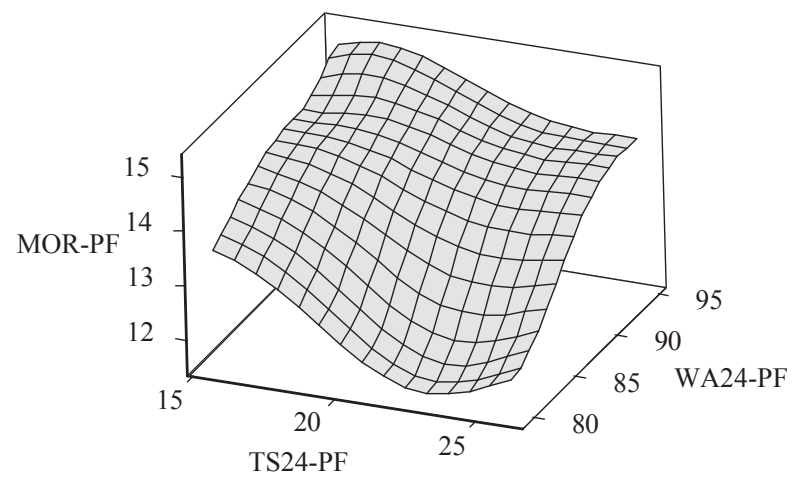

Figure 7 Surface plot between MOR versus WA and TS values in panels produced with phenol-formaldehyde (PF) resin (MOR - modulus of rupture; TS - thickness swelling; WA - water absorption)

Slika 7. Površinski prikaz odnosa MOR, WA i TS vrijednosti na pločama proizvedenima uz dodatak fenolformaldehidne smole (PF) (MOR - modul loma; TS - bubrenje; WA - upijanje vode) verse relationship indicated that both MOR and TS values were in close agreement with the overall strength of the matrix; that is, the higher strength and integrity among wood fibers can be translated into higher MOR values, and consequently lower TS values. However, WA values cannot necessarily be related to the strength of material, but it is closely related to other factors such as porous structure/system of the composite.

Cluster analysis based on the properties studied in the present project demonstrated remote clustering of panels produced with feather and PF-resin containing NC, that is, treatment WF-P-NC (Figure 9). Therefore, based on the properties discussed above and the cluster analysis, it was concluded that addition of feather and NC to panels produced with PF resin would not be recommended due to the unsatisfactory physical and mechanical properties. Close clustering of the two panel treatments produced with PF-resin and $100 \%$ wood fibers with or without NC content (W-P and W$\mathrm{P}-\mathrm{NC}$ treatments) indicated that in these panels, the improvement by $\mathrm{NC}$ was so low that extra expenses for addition of NC would not be commercially recommendable. The same decision was true about panels with feather content and produced with UF resin (WF$\mathrm{U}$ and WF-U-NC treatments).

\section{CONCLUSIONS 4. ZAKLJUČAK}

Wood composite industry is in constant need for raw materials to keep up a continuous production line. Therefore, in the present research project, $10 \%$ of chicken feathers was added to medium-density fiberboard (MDF) furnish to investigate if chicken feathers can be used as part of the mat. Two different resins of urea-formaldehyde (UF) and phenol-formaldehyde (PF) 

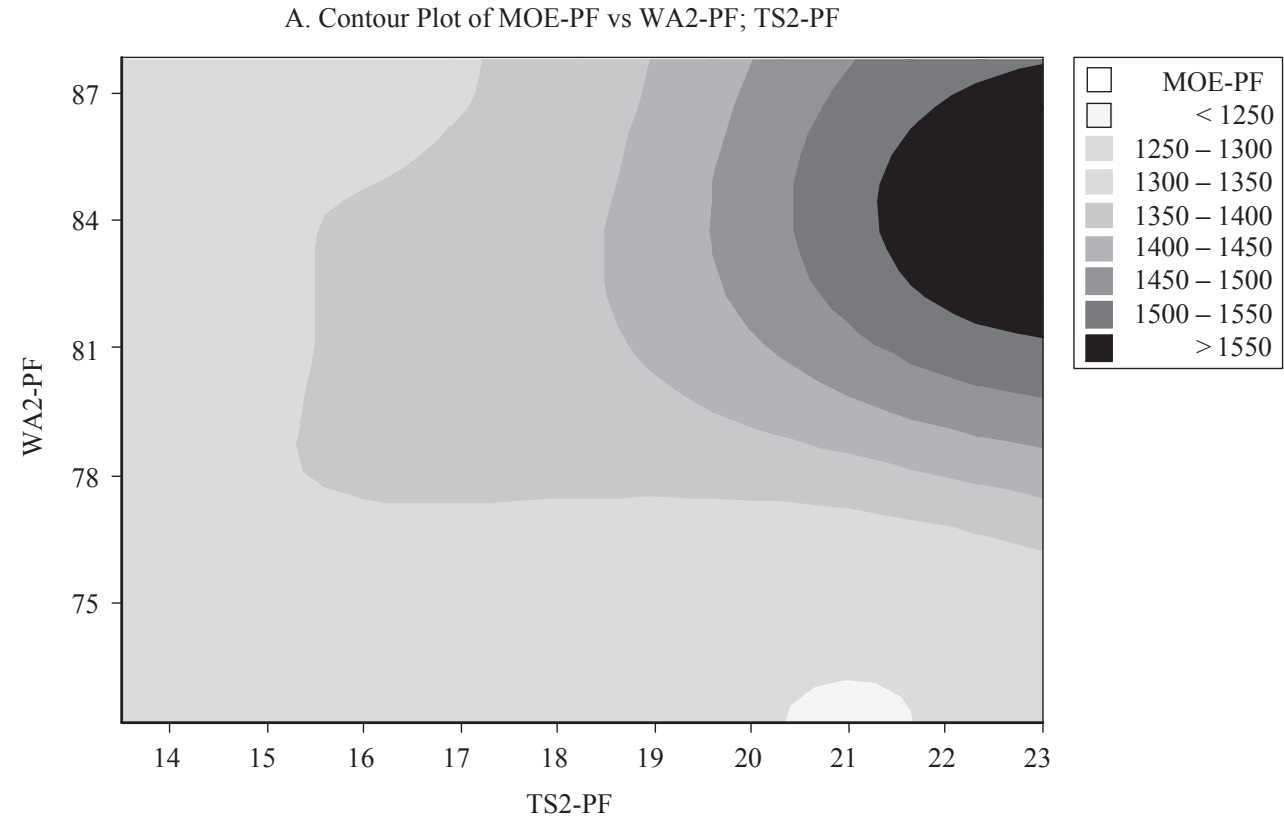

B. Contour Plot of MOR-PF vs TS24-PF; WA24-PF
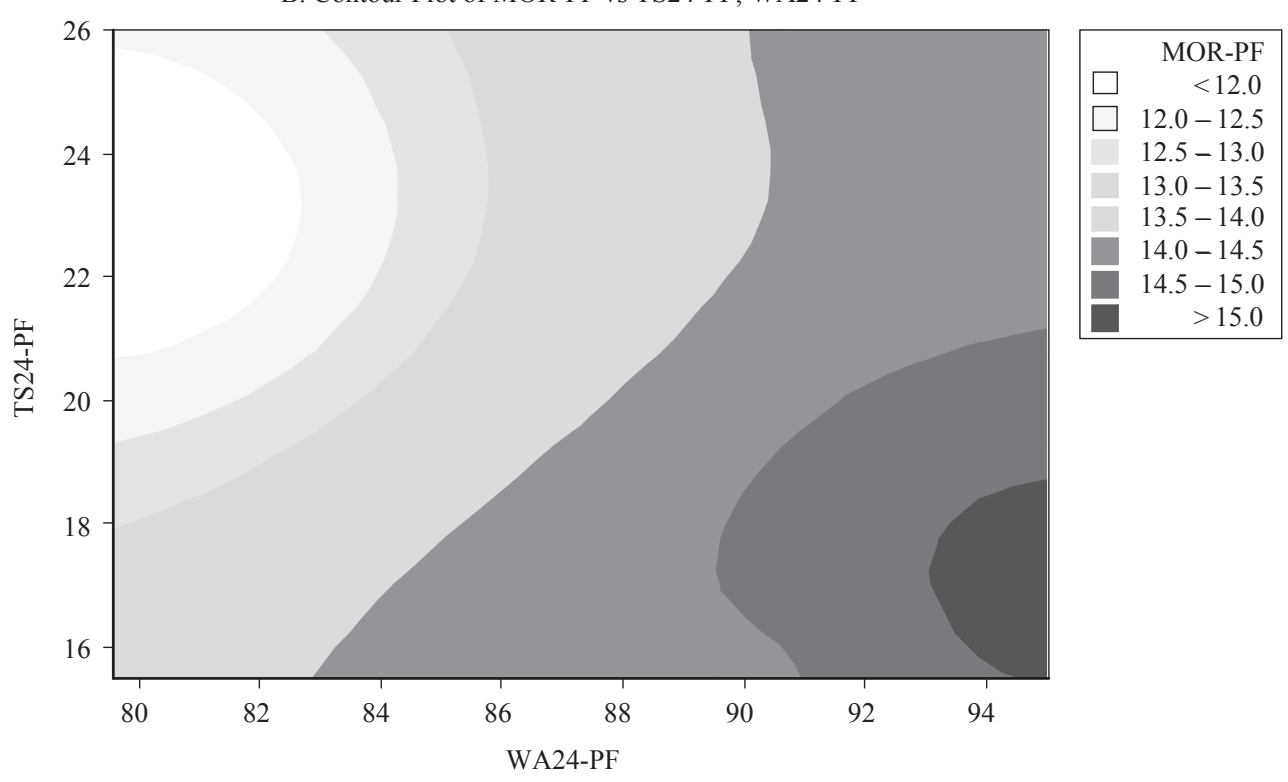

Figure 8 Contour plots between MOE (A) and MOR (B) values versus WA and TS values in panels produced with phenolformaldehyde (PF) resin (MOR - modulus of rupture; TS - thickness swelling; WA - water absorption)

Slika 8. Kontrastni prikaz vrijednosti MOE (A) i MOR (B) u odnosu prema WA i TS za ploče proizvedene s dodatkom fenolformaldehidne smole (PF) (MOR - modul loma; TS - bubrenje; WA - upijanje vode)

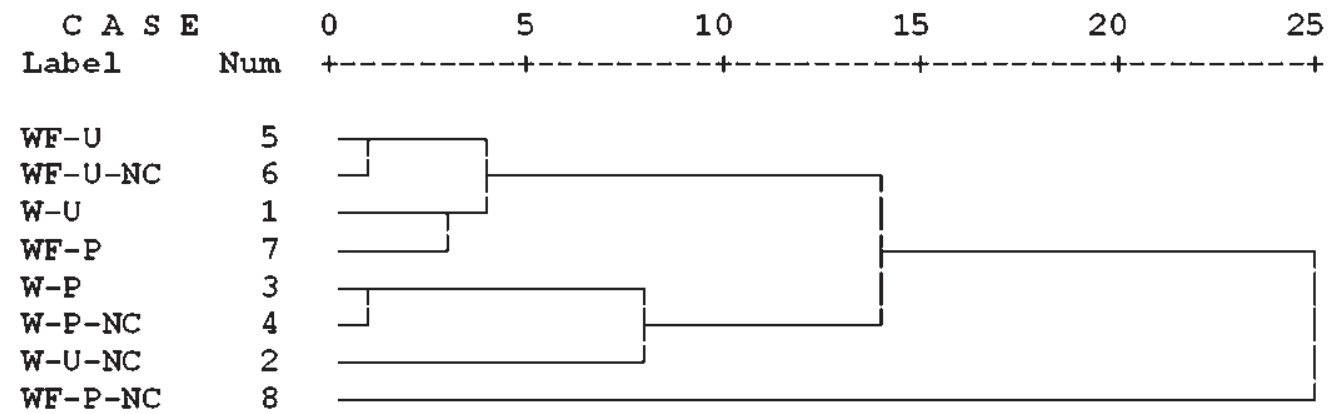

Figure 9 Cluster analysis based on physical and mechanical properties in the present research project (W - wood fibers; F - chicken-feather fibers; U - urea-formaldehyde resin; PF - phenol-formaldehyde resin; NC - nano-clay) Slika 9. Klasterska analiza napravljena na osnovi fizičkih i mehaničkih svojstava određenih ovim istraživanjem (W - drvna vlakna; F - vlakna od pilećeg perja; U - ureaformaldehidna smola; PF - fenolformaldehidna smola; NC - nanoglina) 
were used at $10 \%$ and $8 \%$ contents, respectively. Nanoclay was mixed with the above mentioned resins and sprayed on the furnish to investigate its potential improving effects on physical and mechanical properties. Panels containing PF-resin demonstrated better stability towards water. However, mechanical properties of panels containing UF resin were generally higher; this was partially attributed to the higher UF-resin content (10 $\%$ ). It was concluded that $\mathrm{NC}$ can be recommended only in panels with UF-resin to improve the properties, while in panels with PF-resin, the improvements are not so high to compensate for the accompanying expenses. Moreover, chicken feathers to be added in MDF panels as part of the furnish demonstrated promising results, though they reduced the properties to some extent.

\section{Acknowledgements - Zahvala}

The authors appreciate constant scientific support of Prof. Olaf Schmidt from the University of Hamburg and Alexander von Humboldt Stiftung.

\section{REFERENCES}

5. LITERATURA

1. Ayata, U.; Akcay, C.; Esteves, B., 2017: Determination of decay resistance against Pleurotus ostreatus and Coniophora puteana fungus of heat-treated scotch pine, oak and beech wood species. Maderas Ciencia y tecnologia, 19 (3): 309316. doi.org/10.4067/S0718-221X2017005000026.

2. Acda, M. N., 2010: Waste chicken feather as reinforcement in cement-bonded composites. Philippine Journal of Science, 139 (2): 161-166.

3. Altuntas, E.; Narlioglu, N.; Alma, M. H., 2017: Investigation of the fire, thermal, and mechanical properties of zinc borate and synergic fir retardants on composites produced with PP-MDF wastes. BioResources, 12 (4): 6971 6983.

4. Andrade, A. C. D. A.; Silva, J. R. M. D.; Braga Junior, R. A.; Moulin, J. C., 2016: Distinction of mechanically processed wood surfaces with similar qualities using sunset laser technique. CERNE, 22 (2): 159-162.

5. Arce, N.; Moya, R., 2015: Wood characterization of adult clones of Tectona grandis growing in Costa Rica. CERNE, 21 (3): 353-362.

6. ASTM D1037-99, Standard Test Methods for Evaluating Properties of Wood-Base Fiber and Particle Panel Materials, ASTM International, West Conshohocken, PA, 1999.

7. Bastani, A.; Adamopoulos, St.; Militz, H., 2016: Shear strength of furfurylated, N-methylol melamine and thermally modified wood bonded with three conventional adhesives. Wood Material Science \& Engineering, 12 (4): 236-241.

8. Behling, M.; Piketty, M. G.; Morello, T. F.; Bouillet, J. P.; Mesquita Neto, F.; Laclau, J. P., 2011: Eucalyptus plantations and the steel industry in Amazonia - A contribution from the 3-PG model. Bois et Forets Des Tropiques, 309 (3): 37-49.

9. Behr, G.; Bollmus, S.; Gellerich, A.; Militz, H., 2017: Improvement of mechanical properties of thermally modified hardwood through melamine treatment. Wood Material Science \& Engineering, 12 (1): 14-23.

10. Candan, Z.; Akbulut, T., 2014: Nano-engineered plywood panels: Performance properties. Composites: Part B, 64: 15-161.
11. Daly-Hassen, H.; Kasraoui, M.; Karra, C., 2014: Industrial timber production in Tunisia: Despite reforestation, dependence on imports is increasing. Bois et Forets Des Tropiques, 324 (4): 29-37.

12. de Medeiros, F. C. M.; Gouveia, F. N.; Bizzo, H. R.; Vieira, R. F.; Del Menezzi, C. H. S., 2016: Fungicide activity of essential oils from Brazilian Cerrado species against wood decay fungi. International Biodeterioration \& Biodegradation, 114: 87-93.

13. Eshaghi, S.; Faezipour, M.; Taghiyari, H. R., 2013: Investigation on lateral resistance of joints made with drywall and sheet metal screws in bagasse particleboard and comparison with that of commercial MDF. Maderas Cienca y tecnologia, 15 (2): 127-140.

14. Fernandez-Puratich, H.; Oliver-Villanueva, J. V., 2014: Quantification of biomass and energetic value of young natural regenerated stands of Quercus ilex under Mediterranean conditions. BOSQUE, 35 (1): 65-74.

15. Fernandes, C.; Gaspar, M. J.; Pires, J.; Alves, A.; Simoes, R.; Rodrigues, J. C.; Silva, M. E.; Carvalho, A.; Brito, J. E.; Lousada, J. L., 2017: Physical, chemical and mechanical properties of Pinus sylvestris wood at five sites in Portugal. iForest Biogeosciences and Forestry, 10: 669-670.

16. Figueroa, M.; Bustos, C.; Dechent, P.; Reyes, L.; Cloutier, A.; Giuliano, M., 2012: Analysis of rheological and thermo-hygro-mechanical behaviour of stress-laminated timber bridge deck in variable environmental conditions. Maderas Ciencia y tecnologia, 14 (3): 303-319.

17. Gbetoho, A. J.; Aoudji, A. K. N.; Roxburgh, L.; Ganglo, J. C., 2017: Assessing the suitability of pioneer species for secondary forest restoration in Benin in the context of global climate change. Bois et Forets des Tropiques, 332 (2): 43-55.

18. Hamoush, S. A.; El-Hawary, M. M., 1994: Feather fiber reinforced concrete. Concrete international, 16 (6): 33-35.

19. Harsini, I.; Matalkah, F.; Soroushian, P.; Balachandra, A. M., 2017: Robust, carbon nanotube/polymer nanolayered composites with enhanced ductility and strength. Journal of Nanomaterials \& Molecular Nanotechnology, 6 (3):1-6. http://dx.doi.org/10.4172/2324-8777.1000218.

20. Hill, C. A. S., 2006: Wood Modification: Chemical, Thermal, and Other Processes. John Wiley \& Sons Ltd., pp 260. ISBN: 978-0-470-02172-9.

21. Hosseinkhani, H., 2015: MDF production from date palm pruning residues in pilot plant scale. Iranian Journal of Wood and Paper Science Research, 29 (4): 591-604.

22. Hubbe, M. A.; Smith, R. D.; Zou, X.; Katuscak, S.; Potthast, A.; Ahn, K., 2017: Deacidification of acidic books and paper by means of non-aqueous dispersions of alkaline particles: A review focusing on completeness of the reaction. BioResources, 12 (2): 4410-4477.

23. ISIRI 9044, Wood - Wood-based panels - Particleboards - Specifications. Institute of Standards and Industrial Research of Iran, Iran.

24. Koch, J. W., 2006: Physical and mechanical properties of chicken feather materials. A thesis presented in partial fulfillment of the requirements for the degree of Master of Science in the School of Civil Environmental Engineering; Georgia Institute of Technology, May, 2006.

25. Majidi, R., 2016: Electronic properties of graphyne nanotubes filled with small fullerenes: A density functional theory study. Journal of Computational Electronics, 15: 1263-1268.

26. Malanit, P.; Kyokong, B.; Laemsak, N., 2005: Oriented strand lumber from rubberwood residues. Walailak Journal of Science \& Technology 2 (2): 115-125.

27. Matinise, N.; Fuku, X.; Maaza, M., 2016: Fabrication of Mixed Phase Bimetallic Zinc Cobaltite Nanocomposite 
via Moringa Oleifera Green Synthesis. Journal of Nanomaterial \& Molecular Nanotechnology, 5 (6): 1-7. http://dx.doi.org/10.4172/2324-8777.1000197.

28. Mendes, R. F.; Junior, G. B.; De Almeida, N. F.; Surdi, P. G.; Barbeiro, I. N., 2013: Effects of thermal pre-treatment and variables of production on properties of OSB panels of Pinus taeda. Maderas. Ciencia y tecnologia, 15 (2): 141-152.

29. Pethig, R., 2017: Review - Where is dielectrophoresis (DEP) going? Journal of The Electrochemical Society, 164 (5): B3049-B3055.

30. Sandeep, N.; Sulochana, C.; Kumar, B. R., 2017: Flow and heat transfer in MHD dusty nanofluid past a stretching/shrinking surface with non-uniform heat source/sink. Walailak Journal of Science and Technology, 14 (2): 117-140.

31. Schmidt, O., 2006: Wood and Tree Fungi: Biology, damage, protection, and use. Berlin: Springer; $334 \mathrm{pp}$. doi: 10.1007/3-540-32139-X.

32. Schmidt, O.; Magel, E.; Frühwald, A.; Glukhykh, L.; Erdt, K.; Kaschuro, S., 2016: Influence of sugar and starch content of palm wood on fungal development and prevention of fungal colonization by acid treatment. Holzforschung, 70 (8): 783-791.

33. Suganya, S.; Kumar, P. S.; Saravanan, A., 2017: Construction of active bio-nanocomposite by inseminated metal nanoparticles onto activated carbon: probing to antimicrobial activity. IET Nanobiotechnology, 11 (6): 746-753.

34. Taghiyari, H. R.; Bari, E.; Schmidt, O.; Tajick Ghanbary, M. A.; Karimi, A.; Tahir, P. M. D., 2014a: Effects of nanowollastonite on biological resistance of particleboard made from wood chips and chicken feather against Antrodia vaillantii. International Biodeterioration \& Biodegradation, 90: 93-98.
35. Taghiyari, H. R.; Bari, E.; Schmidt, O., 2014b: Effects of nanowollastonite on biological resistance of mediumdensity fiberboard against Antrodia vaillantii. European Journal of Wood and Wood Products, 72: 399-406.

36. Taghiyari, H. R.; Sarvari Samadi, Y., 2016: Effects of wollastonite nanofibers on fluid flow in medium-density fiberboard. Journal of Forestry Research, 27 (1): 209-217.

37. Tajvidi, M.; Gardner, D. J.; Bousfield, D. W., 2016: Cellulose Nanomaterials as Binders: Laminate and Particulate Systems. Journal of Renewable Materials, 4: 365-376.

38. Valenzuela, J.; von Leyser, E.; Pizzi, A.; Westermeyer, C.; Gorrini, B., 2012: Industrial production of pine tannin-bonded particleboard and MDF. European Journal of Wood and Wood Products, 70: 735-740.

39. Winandy, J. E.; Muehl, J. H.; Micales, J. A.; Raina, A.; Schmidt, W., 2003: Potential of chicken feather fiber in wood MDF composites. Proceedings EcoComp, P20: $1-6$.

40. Winandy, J. E.; Muehl, J. H.; Glaeser, J. A.; Schmidt, W., 2007: Chicken feather fiber as an additive in MDF composites. Journal of Natural Fibers; 4 (1): 35-48. http:// dx.doi.org/10.1300/J395v04n01_04.

\section{Corresponding address:}

Assoc. prof. HAMID REZA TAGHIYARI, Ph.D.

Faculty of Materials Engineering \& New Technologies Shahid Rajaee Teacher Training University (SRTTU) Lavizan, Shabanloo St.

Tehran, IRAN

e-mail: htaghiyari@sru.ac.ir; htaghiyari@yahoo.com 